\title{
Culture-led Urban Regeneration as a Catalyst FOR THE REVITALISATION OF THE ROMANIAN INDUSTRIAL HERITAGE ${ }^{1}$
}

\author{
Cristina Merciu, George Merciu, Mirela Paraschiv, Loreta CercleuX, \\ and Ionuţ IANoș, all Bucharest [Bucureşti]*
}

with 5 figures in the text

\section{Content}

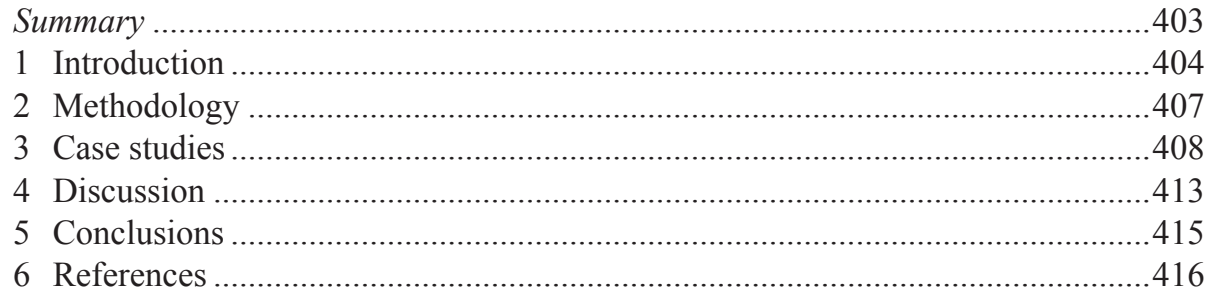

\section{Summary}

Former industrial spaces represent an important territorial asset to direct development and growth processes. Romania possesses a large industrial heritage after the de-industrialisation started in the 1990s. The aim of the study is to highlight the role of cultural regeneration in revitalising the abandoned industrial areas. In Romania's particular case, the conversion of industrial sites is a recent process. Different brownfield industrial sites were chosen as case studies to develop different models of cultural re-use for their re-integration as urban public spaces. The selected

\footnotetext{
$1 \quad$ This study was supported by the UB 1322 project "Integrated and sectorial analyses in trans-scalar territorial dynamics".

* Cristina Merciu et al., PhD. Researchers, Interdisciplinary Center for Advanced Research on Territorial Dynamics, University of Bucharest, 4-12 Regina Elisabeta Blvd., Bucharest, Romania; email: krysten1009@yahoo.com
} 
case studies are part of distinct geographical spaces, with different industrial specificities and periods of service. The re-use proposals of the heritage buildings and main results show that cultural activities represent an important catalyst in revitalising the Romanian industrial heritage. Culture-led regeneration is meant to convert the industrial heritage assets into cultural spaces, with the main goal of emphasising their values (architectural, technological, historical, aesthetical, social). Conclusions evidence that cultural conversion of brownfield industrial sites leads to a higher community quality of life, a better land use, an improved environment, a diversification of economic activities, the conservation of heritage buildings and a generally enhanced attractiveness of the urban environment.

\section{Introduction}

Urban regeneration represents a complex process that involves a multitude of interconnected aspects aiming to economic and social development, built upon the triangle of sustainability (LANG 2005), along with environmental regeneration, optimal valorisation of local resources and cultural heritage conservation. Community involvement plays a fundamental role in conducting a successful urban regeneration process (BEVILACQUA et al. 2013).

Numerous research studies underline that cultural re-use contributes significantly to urban regeneration (Bianchini et al. 1988; Gdaniec 2000; MommaAs 2004; Evans 2005; van de Borg \& Russo 2005; Smidt-Jensen 2007; Homadovski 2009; Stern \& Seifert 2010; Antal \& Antal 2014; Cercleux et al. 2014).

Cultural-led urban regeneration refers to the territorial impact of different cultural activities (RADU 2013) organised by cities at individual level or through developing cultural clusters (STERN \& SEIFERT 2010). The creation of cultural clusters is employed as an alternative source of urban development (MommaAs 2004) through innovation and creativity (Porter 1995, 1998, quoted by STERn \& SeIFert 2010). In many cases, former industrial complexes are chosen as location of different cultural activities organised by specific clusters (MommaAs 2004; SMIDT-JENSEN 2007). Culture received significant attention in recent decades, as more and more urban centres have turned to the arts economy as a substitute for the declining industrial activities (STERN \& SEIFERT 2010).

Cultural-led urban regeneration is associated with multiple positive effects at different territorial dimensions: intensified economic activities, enhanced value on cultural heritage and improved quality of the environment.

The economic impact of culture-led urban regeneration includes the multiplication of jobs (HoMADOVSKI 2009; SASAKI 2010), contributing at the same time to the emergence of a specialised workforce (SCOTT 2006, quoted by SASAKI 2010), increasing the tax 
revenues and promoting the economic re-integration of underprivileged urban areas (McGreogor \& McConnachie 1995, quoted by Lang 2005). Economic development conducted by enhanced cultural activities would also include some qualitative dimensions: improved professional qualification and innovation-led growth (LANG 2005).

Urban regeneration based on cultural activities contributes to the promotion and conservation of local heritage (GDANIEC 2000) by an enhanced sense of place and identity, granting a community the possibility to (re)discover its own culture and history along with learning about the cultural values of other spaces.

Social contribution of the cultural urban regeneration is related mainly to the promotion of gentrification (SMIDT-JENSEN 2007), social inclusion and social cohesion (LANG 2005; SmidT-Jensen 2007; Pereira TeXIEIRA 2010), through greater opportunities for socialisation and contact across different groups of the population by active participation of marginalised groups (such as children, women and immigrants) in local amateur activities (BAyliss 2004; Skot-Hansen 1999, quoted by SMidT-Jensen 2007). At the same time culture-led urban regeneration creates the context for training and participation of the population in community-based cultural activities within a holistic approach focused on social capital and community capacity (BAYLISS 2004; LANDRY 2000; Bianchini 1993, quoted by Smidt-Jensen 2007). This participation of local residents and other population groups in cultural activities supports the sustainability of economic development.

Generally, urban regeneration may result in some negative environmental impacts as well, in relation to the quality of the urban fabric and the natural environment, due to the anthropogenic pressure generated by increased attractiveness of urban space after renovation of the industrial heritage. That is why urban regeneration must be part of territorial planning projects and actions, taking into account the construction of new urban infrastructures and facilities, the modernisation of urban design, the regeneration of brownfield industrial areas (Pereira TexieIra 2010; PAraschiv \& NAZArie 2010) and optimal land use.

The end of the Second World War generated in Europe a restructuration of the economy that led to the transition from the industrially based economy to the post-industrial economy, with the result of social and economic decline for many industrialised urban centres (LANG 2005; CEPOIU 2009; GAvriLidis et al. 2011; CERCLeUX et al. 2012; Cercleux \& Merciu 2013), especially in cases where it was difficult to adapt to new economic activities, mainly for cities with a mono-structured economy (CEPOIU 2009). The process of economic restructuring involved the rationalisation of further developments in the remaining industrial sectors, while, at territorial level, important surfaces of the urban land entered a brownfield state because the $19^{\text {th }}$ century industrial infrastructure became redundant (MommAAs 2004).

Recent research focused on the cultural re-use of brownfield industrial resources as instrument for the regeneration of post-industrial areas (EvANS 2005; RAUTENBERG 
2011; GAVRILIDIS et al. 2011; CizLER 2012). Cultural uses may change the functionality of abandoned industrial buildings and generate economic productivity (MERCIU et al. 2013).

One of the predominantly employed cultural re-uses of former industrial buildings is the transformation into a museum of the derelict buildings with certified historical and architectural value. This policy of culture-led urban regeneration started in France since the period of the French Revolution and it contributed to the conservation of historical buildings (LORENTE 1996) while it was also applied to the specific case of industrial buildings (Alfrey \& Putnam 1992, quoted by Lorente 1996). Several examples of regenerated former industrial sites became real urban symbols: The Orsay train station was converted into the d'Orsay Museum (Paris); the Giovanni Montemartini thermo-power plant (Rome [Roma]) hosts an art museum; the Hamburger Bahnhof (a former train station) in Berlin hosts a new museum for contemporary art ("Museum für Gegenwart"); the former Midland Railway Goods Depot houses turned into the Conservation Centre of the National Museums and Galleries of Merseyside (Liverpool); the water tower Favoriten (Vienna [Wien]) is used as a look-out tower, a museum and a culture venue/exhibition space.

Art and cultural activities are frequently used in assigning new destinations to unused industrial spaces. Industrial heritage, with its vast derelict spaces, has an important potential to acquire new forms of artistic expression. Thus, industrial heritage is an instrument to improve the image of territories under economic decline, by generating their cultural and economic revitalisation. At the same time, the culturalfunctional reorganisation of brownfield sites serves to enhance the cultural vitality and architectural expressiveness of industrial buildings (WANG \& QU 2011).

The conversion of abandoned industrial buildings contributes both to environment regeneration and development as well as to the opportunity to conduct various projects of infrastructure (exhibition centres, for example) and to run new cultural activities that support the economic growth of cities (WANG \& QU 2011).

In the recent context of urban competitiveness, cultural heritage (including industrial heritage) constitutes the main axis of structural and functional reconversion projects, in line with the promoted valorisation of cultural resources and the strengthening of the identity of places. Various cultural heritage re-use actions have an important role in its conservation, together with conferring to it an economic value. In this regard, former industrial buildings are brought back on the real estate market as 'cultural incubators' or places of cultural production and presentation (MOMMAAS 2004).

In Romania, pre-occupations for the valorisation of industrial heritage buildings through functional reconversions intensified in the last years as a result of intense initiatives of specialists in the field. But the process of conversion often meets impediments during the different steps required in the achievement of a successful 
project, as the support of public actors is limited. The indifference of public administration and the bureaucratic burden related to obtaining the required approvals for the functional changes imposed by conversions and the documentation for the classification of industrial buildings as historical monuments interfere negatively with the urban regeneration process in Romania. At the same time, some of the existing buildings of industrial heritage (special architecture, machinery and working tools of an outstanding value) entered a process with actions based on interests of economic gain. Interventions of brutal functional conversion affected a part of the industrial heritage, with buildings being partially or totally demolished or even being torched in order to be declassified and to use the space they occupy for other economic activities and new developments like building new residential spaces. The territorial context of these actions included the de-industrialisation process after the 1990s, the postSocialist industrial restructuring and the capitalist privatisation, in majority, of the industrial units (CERCLEUX \& Merciu 2010).

But there are also in Romania several successful examples of functional conversion of industrial buildings (the former commodity market in Bucharest [București], the former glucose factory of Bucharest, the former paintbrush factory of Cluj-Napoca), having a major urban impact with the result of polarising other important economic activities while supporting the conservation of their original architecture. Many of these actions to re-use the industrial buildings were of cultural influence. They involved a large diversification of the new functions including the opening of museums, cultural and performance centres (BăRbUiCĂ 2012; Radu 2013; MerciU et al. 2013; AnTAL \& Antal 2014; Moțcanu-Dumitrescu 2015). Other re-uses of industrial buildings in Romania meant their adaptation to a new production (warehouses or the change of the initial economic function) (BĂRBUICĂ 2012) or to services requirements - some of the industrial buildings were transformed into kindergartens or hotels (GAVRILIDIS 2011; Radu 2013; Cercleux 2014).

Special attention may be given to the creation of technical museums as an important action in the conservation of industrial heritage. In the 1990s, several technical museums have been established in Romania with the aim to promote the knowledge of various industrial activities or machineries. Some of the most relevant examples are the open air museum for steam locomotives (Sibiu, 1994) and the water museum (Floreşti, Cluj County, 1992) (Merciu et al. 2013).

\section{Methodology}

This analysis is based on recent research focused on the complex problem of cultural regeneration in the case of industrial heritage, with the assessment of the process' positive territorial impact at different levels - economic, social, cultural and environmental. 
The study investigates several proposals of cultural conversion of some brownfield industrial sites in Romania, highlighting the possible effects generated by re-use activities. The proposals of cultural conversion were developed through a complex analysis taking into consideration different characteristics of the industrial buildings selected as case studies: age, current state of conservation, former functionality, the building's interior configuration, the building's suitability to cultural transformation. The selected industrial buildings are included on the cultural heritage list and they are part of several categories of industrial heritage - a former beer factory, a former brick factory, a water tower.

Heritage is analysed through an ecosystemic approach that investigates the relation between the quality of a monument building, the suppliers and the recipients of cultural services. The ecosystemic approach is based on the complex systems analysis of cities, interpreted from the perspective of their metabolism as reflected through the input-output relationship and the determining factors that intervene in the creation of the output, alongside a view on the economic benefits of preserving the heritage (Cercleux et al. 2012).

Field observations included the inventory of different industrial objects and data collection on their different characteristics so that several buildings of industrial heritage were selected in relation with their representativeness for certain defining values (architectural, historical, cultural, social). At the same time, case studies were chosen to evidence the diversity of cultural re-use forms applied to the industrial buildings. These cultural re-uses aim to preserve the former industrial buildings together with their economic valorisation through activities that enhance their role of historical monuments.

\section{Case studies}

\subsection{Bragadiru Brewery (Bucharest)}

The Bragadiru Brewery, built in 1894 in Bucharest, functioned under a different name, the name of the neighbourhood - Rahova Factory - during the Communist period, after it got nationalised in 1948 (Dussolu 2003). The Bragadiru Brewery conducted a similar social role inside the local community as other important breweries in Europe (DuşoIU 2003), completing its economic functionality by an impact on the quality of the urban environment within a cultural approach. So, between 1895 and 1904, Bragadiru Palace was built near the brewery as a place dedicated to recreational activities for the employees and their families (DuşoIU 2003). The main cultural activities held in the palace were occasional dancing events and festivities. After it entered the state property in 1948 , the palace was restored but it continued to be used for various cultural activities (DuşoıU 2003). 
After 1990, the buildings of the former industrial complex were abandoned and they entered a process of strong physical and functional degradation. The privatisation conducted at the end of the 1990s represented a significant downturn for the brewery while the new owners and investors proved to lack interest in continueing its economic activity. Currently, a single building unit of the brewery was part of some restoration actions (Fig. 1), while the rest of the industrial site remained derelict (Fig. 2).

Figure 1: The main building of the former Bragadiru Brewery during its restoration process

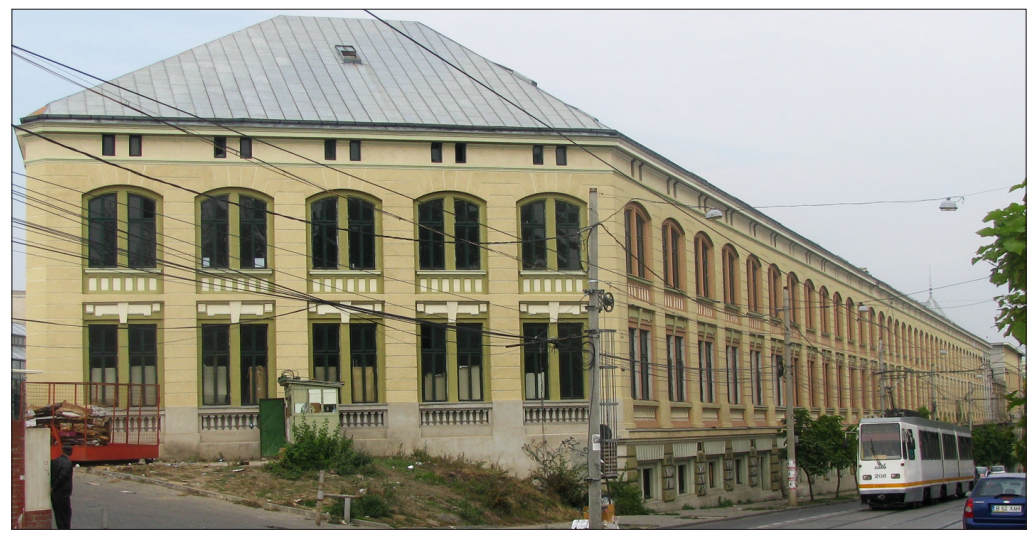

Source: MerCIU 2010

Figure 2: Derelict buildings of the Bragadiru Brewery industrial site

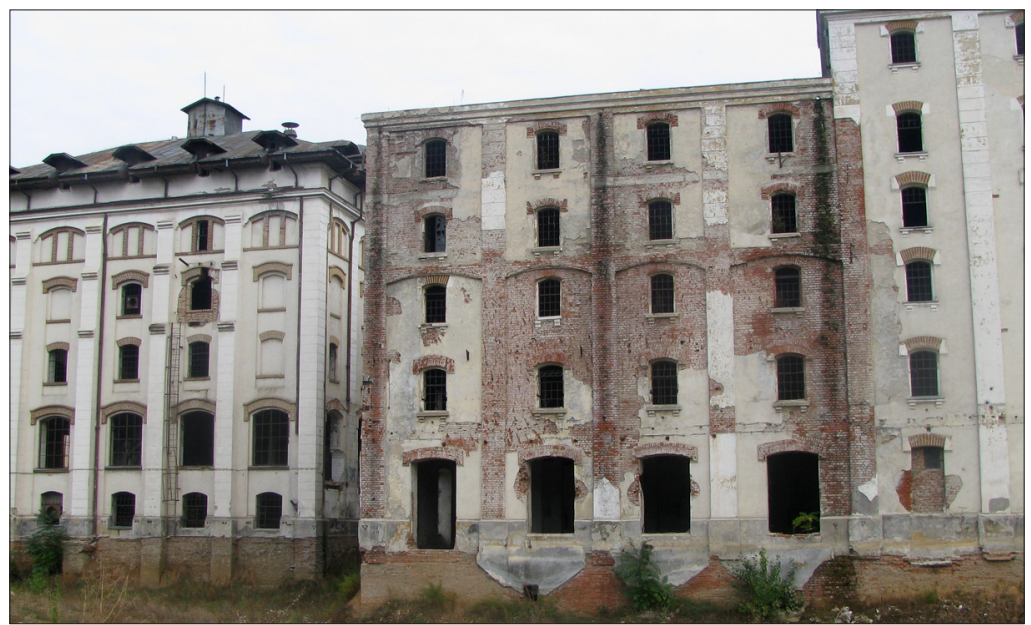

Source: Merciu 2010 
New development projects for this industrial site introduce the current tendencies of urban development in Bucharest (SIMION \& NisTOR 2012) and they include its transformation into a multifunctional commercial hub that will incorporate a shopping mall, a hotel and a business centre (MIREA 2011). An underground parking will represent an additional functional space. The restoration process is part of this development project, which aimed to redesign the buildings by linking them through some shopping passages. While the investment project advances very slowly, many of the heritage buildings remained only freshly painted in a different style from the original. As a result, the conversion of this industrial site lacks a real heritage approach. As a positive aspect, Bragadiru Palace kept its former functionality, i.e. its cultural destination and entered a process of heritage conservation (CERCLEux et al. 2012).

Taking into account its land surface and the number of the buildings, the proposed alternative we have for the regeneration of this former industrial site is its conversion into a dynamic cultural complex destined to diverse specific activities and functionalities: museums with permanent and temporary exhibitions; performance halls for artistic events (music, theatre, dance); office buildings for companies working in the creative industries.

Also, the former Bragadiru Brewery could host an archives centre dedicated to the industrial heritage buildings of Bucharest. This archives centre is of high interest for the sustainable management of industrial heritage in Bucharest, with positive effects at national level through the provision of good practices. The gathering of all documents, plans, photographs, audio and video materials related to different elements of industrial heritage would facilitate research for conservation actions, promote activities with a focus on the sites' and buildings' historical, technological and cultural value, promote educational activities focused on the history of the industrialisation process in Bucharest and across the country, increase knowledge about the extinct (demolished) industrial heritage and raise awareness of the general identity value of former industrial buildings as heritage.

The conversion of the former industrial site into a cultural complex would directly and strongly impact the urban environment at local and city level. The process of culture-led regeneration would socially and economically revitalise the local community while the area would become an active space for diffusing development through urban innovation.

\subsection{Brick factory, Reşiţa}

The refractory brick factory, located in Reşiţa (Banat), was built at the beginning of the $20^{\text {th }}$ century (1905-1906) and it functioned first as a historical monument, both for its historical value and its industrial architectural building design (MERCIU 2011). But after entering a rapid process of physical degradation, instead of being restored, 
the former brick factory was removed from the list of Reşiţa's historical buildings in 2012. This action of the local and central authorities represents one of the many official examples of neglect in relation to industrial heritage.

The process of decay is still active, so that the main structure of the building is in a derelict condition (Fig. 3) suffering also from precipitation - rainwater trickles directly on the building while it infiltrates into the plaster - and being in danger of total collapse in the absence of adequate rehabilitation and restoration measures. Therefore, urgent measures must be taken to conserve and consolidate the building. Restoration of the brick factory would include also the reconstruction of the already damaged part of the building.

\section{Figure 3: The brick factory in Reşiţa in a precarious physical condition}

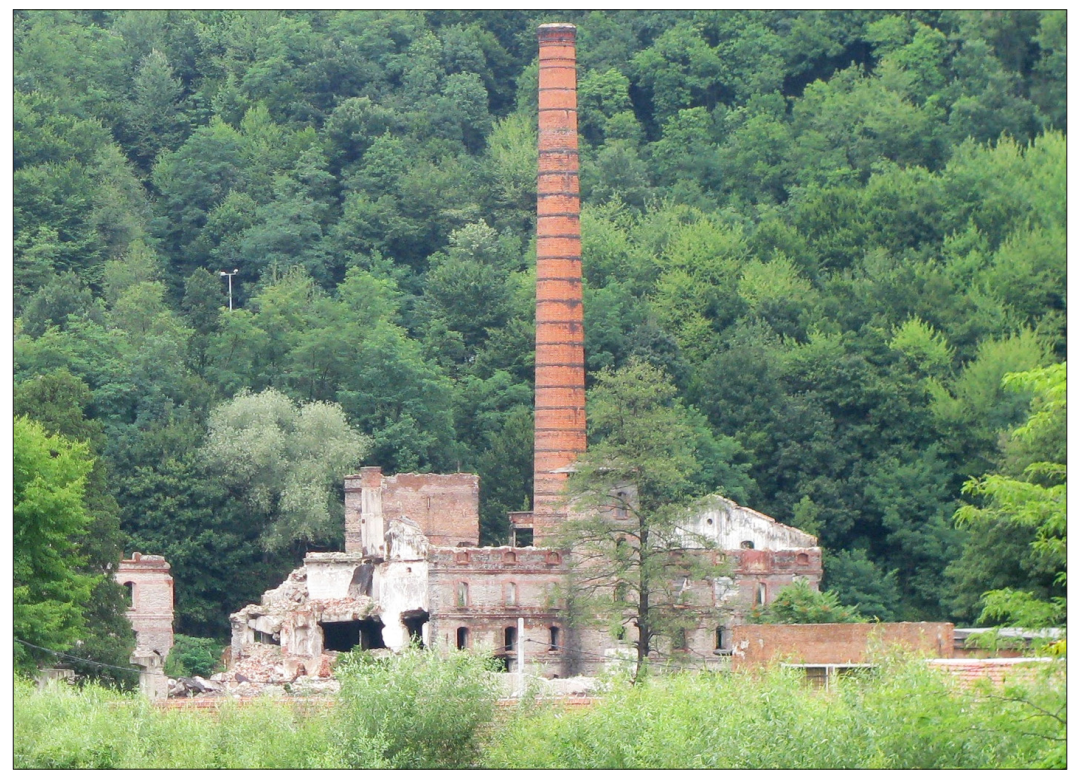

Source: MerCIU 2012

The former brick factory was included as case study in the analysis based on its architectural and technical representativeness. The main building has a special industrial architecture made of brick, while the factory chimney represents the bestpreserved element.

Technically, the brick factory played an important role in the development of the steel factory in Reşiţa. However, in the region have been many brick factories or smaller brick centres. Given its historical importance at regional level, the brick factory would represent the symbol of refractory products industry that could be 
restored and conserved to be transformed into a research and promotion centre focused on the industrial heritage of the area. The research centre should have the interest to conduct a complex study to increase the knowledge on the history of refractory materials industry in the region, highlighting its technological evolution.

Industrial activity involves also the collective memory of factory workers. The industrial heritage research and promotion centre should include a section dedicated to the factory employees documenting their work and life conditions. The industrial building could also host an archive on the refractory industry. The archive could contain materials and documents on the brick factories in the region. The new functionality would offer an adequate means to emphasise the cultural and technological value of the former brick factory.

\subsection{Water tower of the former match factory (Bucharest)}

The water tower located on the industrial site of the former match factory in Bucharest (Fig. 4, 5) was constructed in 1878 inside a larger industrial zone, in the proximity of the stamp factory and the Filaret railway station, on a hilly area of the city.

Figure 4: Water tower of the match factory

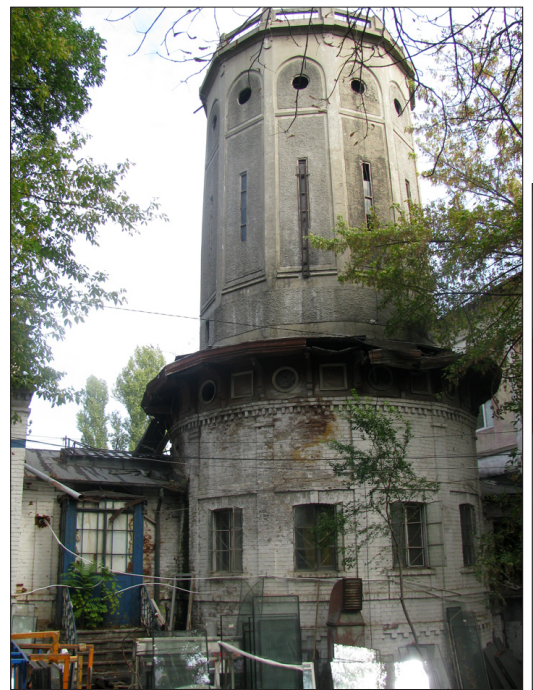

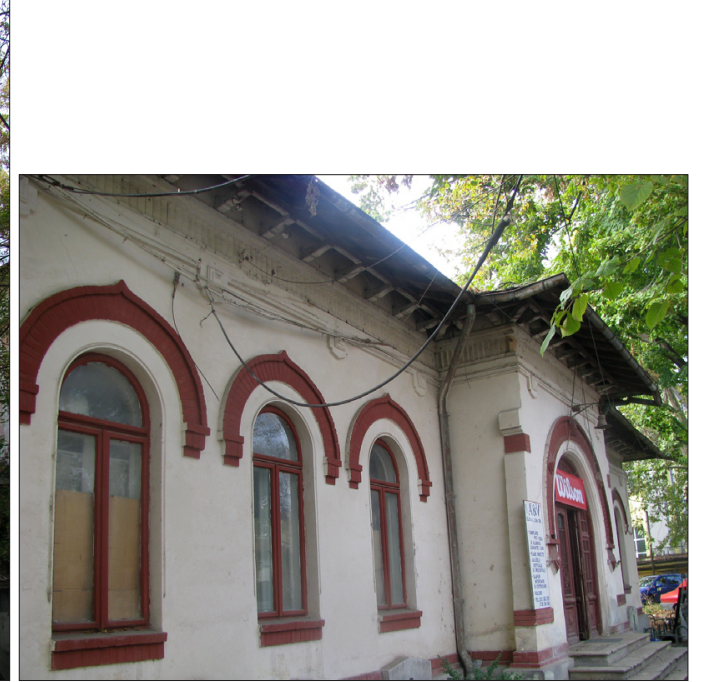

Figure 5: The match factory

Source: CERCLEUX 2012 
The match factory was opened in 1879 and started to produce around 300,000 match sticks on a daily basis, using 30 industrial machines constructed in Belgium and France. Nowadays, the factory is out of use, as it stopped functioning in 2000 (CERcleux et al. 2014). But the main building of the factory is re-used as an office building by a foreign company for sports products.

The water tower was classified as a historical monument (Ministry of Culture 2010) due to its historical and architectural value as a symbol of one of Bucharest's types of industry so that its functional conversion asks for increased involvement and development. The water tower is also unused, but it still has a good conservation condition, although it requires specific rehabilitation interventions. It could be transformed into a match museum with permanent exhibitions of matchboxes produced by the former match factory. The collections of matchboxes would have a significant educational role and they would increase awareness of the industrial heritage as the matchboxes used to be decorated by images of various factories in the country, alongside museums and memorial houses. Temporary exhibitions of the museum could display matchbox collections from various other countries.

The culture-led conversion of the water tower into a museum would represent the optimal solution to emphasise the value of this underutilised former industrial space, while it employs an increased potential of diffusing good regeneration practices as it would represent the first technical museum of this type in Romania.

\section{Discussion}

In Romania, capitalisation of technical and industrial heritage raises increasing problems due to fragmented and unsustainable management of industrial sites. This situation is a consequence of the privatisation process launched in the 1990s, when the industrial buildings were bought by investors that often have different development aims and took actions in opposition to conservation measures required.

Conversion proposals for the buildings of industrial heritage selected as case studies evidence different forms of cultural re-use in accordance with ongoing conservation to highlight their architectural, technological, historical and cultural value.

In the context of a general decline of industrial activities and with a focus on production functionality, culture-led conversion of industrial units and sites represents the adequate approach to promote urban regeneration and sustainable development. Conservation of industrial heritage assets preserves also the identity of territories where industry played an important role. Industrial buildings are specific identity features due to both their historical past and physical characteristics representative for the area and the local community. 
Industrial heritage re-use is a difficult process that has to imply careful research of the former industrial site to investigate its compatibility with the adequate re-use related to the best means of in situ conservation, while industrial heritage buildings as such need to meet certain standards of size, interior room design, degree of conservation and location.

As a result of different periods of industrialisation in Romania, there can be found many large industrial spaces located inside the city, at the periphery of the central area, which can be functionally transformed and re-used as cultural centres, museums or exhibition halls. Culture-led regeneration refers also to other forms of cultural conversion, in addition to museification, even in the case of derelict industrial buildings that lost their technological value during the period of abandonment. Cultureled regeneration implies first the restoration and rehabilitation of the heritage building, followed by its functional conversion according to its status as historical monument. A better understanding and implementation of the conservation process requires its correlation with a process of capitalisation of the industrial heritage potential.

The case studies selected evidence that culture conversion may represent the best solution (and sometimes the only adequate one) to capitalise an industrial heritage building in connection with regeneration of the entire surrounding area and community involved, through the attraction of new investments, the creation of jobs and new incomes for the local population. Implementing the suggestions of cultural functionality may constitute the adequate support to ensure continuity in the process of transforming the former industrial resources of land and buildings into active and attractive cultural features.

The examples included in the analysis also draw attention to the fact that the implementation of cultural re-use plans is totally dependent on available financial means and decisions and interventions taken at every administrative level. Policy making should include the preservation of technical and industrial heritage as an objective of economic policies aiming at planning for a local, regional and national development.

Romanian industrial heritage raises issues that require an approach closely linked to the current socio-economic context so as to deal with the current challenges that, most of the time, impede the conservation and re-use process. The absence of previous experience (before the 1990s) in the conservation and regeneration of industrial sites represents a continuous obstacle to capitalise the industrial assets according to their preservation needs.

Cities provide ideal workspaces for cultural activities, cultural production and consumption. The importance of culture as an engine of urban development can be fully determined by considering its role in cities' regeneration (VAN DE BORG \& RUSSO 2005). Urban development investments into new cultural infrastructures (flagship museums, exhibition and performance halls) and activities (innovative festivals) contribute to increasing the attraction of cities by creating a modern urban image (GRODACH 2008) 
and a particular urban identity by symbols and cultural landmarks (VAN DE BORG \& Russo 2005). Berlin with its Museumsinsel, Vienna with its Museumsquartier, Paris with its Centre Pompidou or Rotterdam with its Kunsthal represent examples of cities associated with some cultural features that contributed to the modelling of their urban identity.

Because of its historical, technological, architectural and social significances industrial heritage constitutes also an important factor in constructing a territory's identity while the re-use of industrial heritage positively impacts and supports the urban regeneration process (MERCIU et al. 2011). Lately, there is an increasing interest in using cultural resources, both for the inhabitants' participation in urban community life and for urban economic revitalisation through gaining financial capital out of cultural production and consumption (SMIDT-JENSEN 2007).

\section{Conclusions}

Industrial heritage assets are part of a territory's identity and material culture, so cultural regeneration constitutes an important direction of urban development. Cultural regeneration involves the preservation of industrial heritage buildings together with measures of economic revitalisation through their transformation into active cultural spaces that pursue to display the patrimony assets of industrial technique and identity.

A high concern of a given society or community for conservation and optimal capitalisation of its cultural resources indicates awareness and good knowledge related to sustainable development.

The models of industrial heritage conversion highlighted show the need to use economic interests as catalyst for urban regeneration in the context of declined production activities. Within this long-term objective, conversion of industrial buildings achieves a second role of adequate conservation while cultural re-uses employ minimum negative impacts on the physical condition of a heritage building.

Conversion of brownfield industrial sites within a culture-led regeneration process implies multiple positive effects such as the revitalisation of peripheral or abandoned industrial areas, the conservation, promotion and capitalisation of different elements of local heritage, while generating new economic activities and jobs that support further urban development. 


\section{References}

Antal R., Antal A. (2014), Conversion of disused spaces as theatrical spaces. In: Urbanism, Architecture, Construction, 5, 2, pp. 39-46.

BĂRBUiČ̃ L. (2012), Performativity of public space. Strategies related to industrial heritage. In: Urbanism, Architecture, Constructions, 3, 4, pp. 39-44.

Bayliss D. (2004), Denmarks creative potential. The role of culture within Danish urban development strategies. In: International Journal of Cultural Policy, 10, 1, pp. 5-28.

Bevilacqua C., Calabrò J., Maione C. (2013), The role of community in urban regeneration: mixed use area approach in USA. In: Schrenk M., Popovich V., Zeile P., Elisei P. (eds.), Proceedings Real Corp 2013, 20-23 May 2013, pp. 1361-1365. Schwechat.

Bianchini F., Fisher M., Montgomery J., Worpole K. (1988), City centres, city cultures: The role of the arts in the revitalization of towns and cities. Manchester, The Centre for Local Economic Development Strategies.

Ceporu A.-L. (2009), Rolul activităților industrial în dezvoltarea așezărilor din spațiul metropolitan al Bucureștilor. Universitară Publishing House, Bucharest.

Cercleux A.-L., Merciu C., Peptenatu D. (2014), Conversion of water towers - an instrument for conserving heritage assets. In: Urbanism, Architecture, Construction, 5, 2, pp. 3-20.

Cercleux A.-L., Merciu F.-C. (2010), Patrimoniul tehnic și industrial din Romania. Valorificare, riscuri și perspective de dezvoltare. In: Annals of the Professional Association of Romanian Geographers, 1, pp. 45-54.

Cercleux A.-L., Merciu F.-C. (2013), Effects of metropolitan economic reorganization in the Bucharest-Ilfov and Southern Muntenia development regions. In: Annals of the University of Oradea, 2, pp. 308-320.

Cercleux A.-L., Merciu F.-C., Merciu G.-L. (2012), Models of technical and industrial heritage re-use in Romania, Proceedings of Landscape, Environment, European Identity, 04-06 November 2011, Bucharest. In: Procedia Environmental Sciences, 14, pp. 216-225.

CizLer J. (2012), Urban regeneration effects on industrial heritage and local community - case study: Leeds, UK. In: Sociologija i prostor, 50, 193, 2, pp. 223-236.

Duşoru C. (2003), Fabricile de bere în patrimoniul viitorului: considerații generale și analiză comparativă a unor studii de caz. In: Revista muzeelor, 3-4, pp. 76-83.

Evans G. (2005), Measure for measure: Evaluating the evidence of culture's contribution to regeneration. In: Urban Studies 42, 5-6, pp. 959-983.

Gavrilidis A., IoJĂ C., SAGHin I. (2011), Urban regeneration through industrial restructuring of brownfields. In: MeJíA I.F., BAOXING Q. (eds.), Proceedings of $47^{\text {th }}$ ISOCARP Congress, pp. 1-12. Wuhan, International Society of City and Regional Planners (ISOCARP).

GDANIEC C. (2000), Cultural industries, information technology and the regeneration of postindustrial urban landscapes. Poblenou in Barcelona - a virtual city? In: GeoJounal, 50, pp. 379-387.

Grodach C. (2008), Museums as Urban Catalysts: The Role of Urban Design in Flagship Cultural Development. In: Journal of Urban Design, 13, 2, pp. 195-212.

Homadovski A. (2009), Transformations in cultural institutions - contemporany museum destinations and influences of industrial branding values. In: Prostor, 17, 2, pp. 389-395.

LANG T. (2005), Insights in the British debate about urban decline and urban regeneration. Leibniz Institute for Regional Development and Structural Planning $<$ http://www.irs-net. de/download/wp_insights.pdf> 
LORENTE J.P. (1996), Museums as catalysts for the revitalization of ports in decline: Liverpool and Marseilles. In: Lorente P. (ed.), The role of museums and the arts in the urban regeneration of Liverpool, pp. 36-59. Leicester, Centre for Urban History, University of Leicester.

Merciu C., Merciu G.-L., Cercleux L., Draghici C. (2013), Conversion of industrial heritage as vector for cultural regeneration. In: Procedia Social and Environment Sciences, 122, pp. 162-166.

Merciu G.-L. (2011), Monumentele istorice din municipiul Reşiţa - abordare geografică. In: Annals of Professional Association of Romanian Geographers, 2, pp. 39-52.

Ministry of Culture (ed.) (2010), List of Historical Monuments, Bucureşti.

Mirea D.A. (2011), Industrial Landscape - a Landscape in Transition in the Municipality Area of Bucharest. In: Forum Geografic, 10, 2, pp. 295-302.

MommaAs H. (2004), Cultural clusters and post-industrial city: towards the remapping of urban cultural policy. In: Urban Studies, 41, 3, pp. 507-532.

Moțcanu-Dumitrescu M.-Al. (2015), Bucharest municipality competitive local economic development through urban regeneration of destructured industrial areas. In: Urbanism, Architecture, Construction, 6, 1, pp. 37-56.

Paraschiv M., Nazarie R. (2010), Regenerare urbană a siturilor de tip brownfield. Studiu de caz: zonele industrial din Sectorul 3, Municipiul București. In: Annals of the Professional Association of Romanian Geographers, 1, pp. 95-107.

Pereira Texieira J.M. (2010), Urban Renaissance: the role of urban regeneration in Europe's urban development future. In: Serbian Architectural Journal, 711, 4, pp. 97-114.

RADU B. (2013), Cultural tourism as a mean of industrial heritage for economic re-generation of former mining areas. In: Transylvanian Review of Administrative Sciences, 33, pp. $138-158$.

RAUtenBerg M. (2012), Industrial heritage, regeneration of cities and public policies in the 1990s: elements of a French/British comparison. In: International Journal of Heritage Studies, 18, 5, pp. 513-525.

SASAKI M. (2010), Urban regeneration through cultural creativity and social inclusion: rethinking creative city through a Japanese case study. In: Cities, 27, pp. S3-S9.

Simion G., Nistor C. (2012), Spatial structure changes inside post-communist capital city of Bucharest. In: Human Geographies, 6, 1, pp. 79-89.

SMidT-JENSEN S. (2007), The role of culture and creativity within urban development strategies. Outlining a theoretical framework for analysing Scandinavian cities. Center for Strategic urban Research-Realdania Research <http://byforskning.ku.dk/filer/wp_8.pdf>

Stern M.J., Seifert S.C. (2010), Cultural clusters: the implications of cultural assets agglomeration for neigbourhood revitalization. In: Journal of Planning Education and Research, 29, pp. 262-279.

VAN DE Borg J., Russo A.P. (eds.) (2005), The impact of culture on the economic development of cities. Rotterdam, European Institute for Comparative Urban Research (EURICUR), Erasmus University Rotterdam.

WANG W., Qu G. (2011), From old factory to red house: analysis on cultural theme strategy in built environment regeneration and design. In: Advanced Materials Research, 224, pp. 250-254. 